\title{
Article
}

\section{Figures of terror: The "zombie" and the Haitian Revolution}

Hoermann, Raphael

Available at http://clok.uclan.ac.uk/16036/

Hoermann, Raphael ORCID: 0000-0001-6156-8431 (2017) Figures of terror: The "zombie" and the Haitian Revolution. Atlantic Studies: Literary, Historical and Cultural Perspectives, 14 (2). pp. 152-173. ISSN 1478-8810

It is advisable to refer to the publisher's version if you intend to cite from the work. http://dx.doi.org/10.1080/14788810.2016.1240887

For more information about UCLan's research in this area go to http://www.uclan.ac.uk/researchgroups/ and search for < name of research Group>.

For information about Research generally at UCLan please go to http://www.uclan.ac.uk/research/

All outputs in CLoK are protected by Intellectual Property Rights law, including Copyright law. Copyright, IPR and Moral Rights for the works on this site are retained by the individual authors and/or other copyright owners. Terms and conditions for use of this material are defined in the policies page.

\section{CLoK}

Central Lancashire online Knowledge www.clok.uclan.ac.uk 
Raphael Hoermann (2016): Figures of terror: The "zombie" and the Haitian Revolution, Atlantic Studies: Global Currents, DOI:

10.1080/14788810.2016.1240887

To link to this article:

http://dx.doi.org/10.1080/14788810.2016.1240887

Figures of terror: The "zombie" and the Haitian Revolution

\section{Raphael Hoermann}

ABSTRACT

This article investigates the relation of the figure of the zombie to the Haitian Revolution, the only successful slave revolution in the Atlantic World. While existing research often stresses the strong link between the zombie and the slave, this is not borne out by the contemporary discourse on the Haitian Revolution. Whereas horror and terror are associated with the zombie from its inception, it is only with the US occupation of Haiti (1915-1934) that US-American writers and directors invented the zombie of popular North Atlantic culture: a soulless slave without consciousness directed by a zombie master. As I argue, this amounts to a neo-colonialist act of symbolic re-enslavement of the self-emancipated Haitians. This time they are deprived not merely of their freedom as under the slave regime, but even of their consciousness.
KEYWORDS

Zombie; Haitian Revolution;

Haitian history; the Gothic;

North Atlantic racist

stereotypes; slavery; race;

Madison Smartt Bell; William

B. Seabrook; White Zombie 
Although largely "erase[d]", "trivialized" and "silenced" in mainstream North Atlantic historiography until recently, ${ }^{1}$ the Haitian Revolution marks one of the most significant cataclysms in the Age of Revolution, besides "the Industrial, American, and French Revolution". ${ }^{2}$ As the only successful slave revolution and the first modern anti-colonial revolution, it decisively challenged North Atlantic hegemony and has constituted a milestone in world history. As leftist scholars and writers from C.L.R. James in his mould-breaking Marxist history The Black Jacobins (1938) over African American writers such as Langston Hughes in his play The Emperor of Haiti (1963) to political philosophers such as Nick Nesbitt and Peter Hallward and present-day historian of slavery Robin Blackburn as well as literary critic Philip Kaisary have contended Haiti forms the crucible of transatlantic revolutionary liberation, in which both human rights and the concept of "universal emancipation" from race and class oppression were forged. ${ }^{3}$ This universalist approach stands in marked contrast to the original limitations that sought to circumscribe the universalist potential of les droits de l'homme et du citoyen to the white, male bourgeois, who alone qualified for citizenship and hence the full rights of man. ${ }^{4}$ The revolution's challenges and alternatives to Eurocentric notions of Enlightenment and modernity have been extensively reflected in recent transatlantic scholarship that has become known as the "Haitian Turn".

For most of its North Atlantic contemporaries, however, the Haitian Revolution constituted an immense challenge and provocation: it cost France its most profitable colony and posed a risk to the transatlantic economic order based upon the slave trade, plantation slavery, and the trade between colonies and metropolitan centres. Perceived as a "terrifying monstrosity", this act of African Caribbean revolutionary self-emancipation has been demonised from its inception. ${ }^{6}$ The North Atlantic world established a virulently negative racist discourse on the Haitian Revolution - and subsequently Haiti and its citizens - that continues to inform perception of the country and its inhabitants across various media. As Gina Athena Ulysse points out, there has existed a pervasive and perverse "racialization of Haitians that so often goes unspoken in mainstream accounts". ${ }^{7}$ Hegemonic North Atlantic discourse on Haiti is replete with repetitive and racist tropes of horror and terror that frequently cast it as the Caribbean's Heart of Darkness, occupying the place of the "most histrionic example[e] of Africa's continental darkness", as Michael Dash emphasises. ${ }^{8}$ I have dubbed this ideological-narrative mode that - through tropes of horror and terror racially demonises Haiti, Haitians and (sometimes tacitly) its revolution as the "Haitian Gothic".

The figure of the zombie - in combination with allegations of cannibalism - has been prominently employed as such a Gothic trope of horror and terror to demonise Haiti and particularly its African Caribbean religion as a black savage practice. ${ }^{10}$ As Michel Laguerre asserts, North Atlantic discourse has "consistently identified the country with Voodoo meaning cannibalism, zombi and the backwardness of its supposed cannibal practise". ${ }^{11}$ By engaging with the discourse on the zombie from its inception, I want to trace the role the figure of the zombie has played in the demonisation of Haiti, its revolution and its inhabitants and explore whether it could be considered a key trope of the Haitian Gothic. Consequently, I will neither focus on the distinctly different manifestations of 
the zonbi in Afro-Haitian religion and folklore, nor on Elizabeth MacAlister's view that "Haitian intellectuals often used the image of the zonbi as metaphor for the existential dilemmas of life under foreign-backed postcolonial dictatorships". ${ }^{12}$

After discussing the zombie as a trope of the Haitian Gothic, this article will move on to debate the common but flawed analogy of the slave and the zombie. After demonstrating how the zombi has been used as a counter-revolutionary horror trope in Madison Smartt Bell's trilogy of historical novels on the Haitian Revolution, the final section will discuss if the analogy of the zombie to alienated labour may harbour the potential to transcend its counter-revolutionary configuration and transform it into a more emancipatory figure.

The revolutionary self-emancipation of the Haitian slaves and the Haitian Gothic: A continuing challenge to North Atlantic hegemony

Understanding the continuing racist demonisation of Haiti in North Atlantic discourse as the "manifestation of blackness in its worst form" requires going back to Haiti's revolutionary origins. ${ }^{13}$ By claiming independence in 1804 , the founding of the postcolonial state of Haiti as a "Black Republic" challenged the British, French and Spanish colonial empires in the Caribbean and in America and also white supremacy in general. Its 1805 Constitution contained not only an attack on slavery and colonialism, as it abolished slavery in perpetuity (Article 2) and prohibited any non-Haitians from holding property (Article 12). But, crucially, it further stipulated in Article 14 that "from now on the Haitians are only known by the generic denomination of blacks". ${ }^{14}$ While the article's immediate goal probably was to heal the bitter rifts between black and mixed-race Haitians, the former slaves the former free people of colour, it marks one of the first positive affirmation of black as a "political rather than [pseudo-]biologically category". ${ }^{15}$ As such it threw down the gauntlet to the dominant racist North Atlantic discourse that portrayed blackness as the epitome of negativity, savagery and bestiality.

There were further more material challenges, such as to the region's slavery plantation economy, the motor of the transatlantic economy. The Haitian Revolution conjured up the spectre of further slave revolutions in the Caribbean or the USA. ${ }^{16}$ In 1799, the then VicePresident of the United States and slave owner Thomas Jefferson already feared that trade with the "cannibals of the terrible republic" - he was referring to Saint-Domingue under the black Governor Toussaint Louverture - would spread inflammatory revolutionary ideas among the slaves of the Southern states. ${ }^{17}$ Haiti's first ruler Dessalines later turned the tables on such slanderous horror images of the Haitian Revolutionaries. Trying to justify his massacres of the remaining French colonialists in Haiti, Dessalines fashioned himself as the avenger not only of the crimes of colonialism and slavery committed in the erstwhile French colony but the entire Americas. For him, the Europeans colonialists not the Haitian revolutionaries are the savage cannibals: "Yes, we have paid them back, these true cannibals, war for war, outrage for outrage. Yes, I have saved my country. I have avenged America". ${ }^{18}$

Dessalines' powerful riposte to decades of vicious defamation, of which Jefferson's reference to the former slaves as "cannibals" is just one of numerous examples, suggests that origins of the horror-laden discourse on Haiti are contemporaneous with the revolution. It already characterised the endlessly recycled atrocity stories about the 1791 slave revolt that started the revolution which drastically illustrated the alleged "fury of the can- 
nibals" ${ }^{19}$ Moreover, this horror discourse constitutes a response to the diverse challenges and convulsions of the Haitian Revolution. As the African American abolitionist and US ambassador to Haiti Frederick Douglass noted tellingly in 1893, Haiti had been demonised as "a very hell of horrors" from its independence onwards.$^{20}$ The literary critic Lizabeth Paravisini-Gebert even regards the Haitian Revolution as "the foundational narrative of the Caribbean Gothic, [...] the obsessively retold master tale of the Caribbean's colonial terror". ${ }^{21}$ The North Atlantic discourse on Haiti has been dominated by a demonising Gothic aesthetic that proliferates a reductively racist caricature of Haiti as "miserable, horrifying, black, ugly". ${ }^{22}$

These racist verdicts form part of an ideological rhetorical mode, the "Haitian Gothic", by which I understand the excessive use of tropes of horror and terror predominantly to demonise Haiti, the Haitians and their history. ${ }^{23}$ North Atlantic depictions of the slave revolution repeatedly draw upon horror scenarios, and the zombie functions as one of the tropes of terror used therein. Even if not always explicitly mentioned, the Haitian Revolution haunts these horror narratives of Haiti, its people and its history. As I have shown these narratives of the "Haitian Gothic" have their roots in the Haitian Revolution, in particular in the slaves' double self-emancipation from slavery and colonialism. The Atlantic World has viewed this as a "crime of lèse-majesté" and as Haiti's "original sin", as the subsequently sacked envoy to Haiti of the Organization of American States Ricardo Seitenfus has claimed. ${ }^{24}$

Stressing the implications of the Haitian Revolution for race and racism, Gina Athena Ulysse in her recent timely intervention Why Haiti Needs New Narratives (2015) locates the revolution and its profound challenges to the colonial transatlantic order at the root of the subsequent and ongoing racist narratives of Haiti in the North Atlantic discourse. It has featured as the epitome of abject blackness, which equates utter negativity with black people, black bodies and the black state of Haiti, precisely because it threw down the gauntlet to white supremacy and its attendant socio-economic institutions of slavery and colonialism:

Haiti and Haitians remain a manifestation of blackness in its worst form, because, simply put, the unruly enfant terrible of the Americas defied all European odds and created a disorder of all things colonial. Haiti had to become colonialism's bête noire if the sanctity of whiteness were to remain unquestioned. ${ }^{25}$

As Ulysse implies, the continuing status of Haitians as the North Atlantic's bete noire - literally black and dehumanised - has to be traced back to the Haitian Revolution. As pointed out, it countered the pseudo-biological category of the black race with all its racist implications of inferiority, savagery, etc., with a political definition of blackness, of a postcolonial and post-slavery state. Haiti's revolutionary self-emancipation from slavery and colonialism has constituted a major onslaught on white supremacy and sanctity of whiteness.

Most abolitions of slavery in the Atlantic world were enacted by the colonisers who bestowed upon the enslaved, what Marcus Wood has termed, "the horrible gift of freedom" ${ }^{26}$ Emancipation from above constitutes both a poisoned chalice and an illegitimate gift since it was neither the European's right to deprive the Africans of their freedom, nor to restore it to them. The Haitian Revolution exploded the propagandistic myth of the white, god-like, emancipator, be his name Wilberforce, Schœlcher or Lincoln, graciously granting freedom to the supplicating slave. As Fanon acerbically comments, this emancipation myth has been monumentalised by the countless figures of the white liberator "car- 
essing the frizzy hair of the docile black man whose chains have just been broken". ${ }^{27}$ By stark contrast, as Frederick Douglass emphasises, "the freedom of Haiti was not given as a boon, but conquered as a right!! 28 The North Atlantic world still has not forgiven Haiti for this deed of self-liberation which configures freedom as a right won through struggle, rather than as a "favour" granted by the white masters who "grudgingly decided to raise the animal-machine man to the supreme rank of man". ${ }^{29}$ As Sidney Mintz sums up the enduring consequences of Haitian self-emancipation: "The inescapable truth is that 'the world' never forgave Haiti for its revolution, because the slaves freed themselves". ${ }^{30}$ One form of continuing punishment for this enormous act of transgression consists in the massive proliferation of lurid horror narratives about Haiti and its revolution.

As I will show, the horror trope of the zombie in the North Atlantic discourse forms part of this wider rhetorical-ideological revenge attack of the Haitian Gothic. It contributes to cementing the (neo-) colonialist Gothic trope of Haiti as the Caribbean's Heart of Darkness. As the British anthropologist Francis Huxley alleges in the preface of his book on vodou The Invisibles (1966), Haiti is one of darkest places on earth, "[n]otorious for its voodoo and its zombis, $[\ldots]$ its poverty is disgusting, its politics horrible, its black magic a matter for dismay". ${ }^{31}$ Besides voodoo and cannibalism, the zombie frequently figures as the third horror trope in racist scenarios of black savagery in Haiti.

The slave and the zombie: a flawed analogy?

Wile the slaves in what was the most profitable colony in the Caribbean, Saint-Domingue, liberated themselves, the figure of the zombie seems to re-enslave the Haitians. The zombie can thus be seen as an important trope closely associated with slavery within the "Haitian Gothic". While William Seabrook's 1929 sensational travelogue is one of the first Anglophone texts to explicitly refer to the zombie as a "slave", ${ }^{32}$ the zombie as a forced labourer is also found shortly afterwards in Melville Herskovits's ethnological field study and Zora Neale Hurston's folklorist study. ${ }^{33}$ It included - as she claimed - the first ever photograph of a zombie: a blurred close-up of a black woman (possibly mentally ill) in ragged cloth with her eyes closed entitled "Felicia Felix-Mentor, the Zombie". ${ }^{34}$

The zombie embodies the slaves' utter alienation, their total lack of freedom and the loss of all of their rights. As a zombie, only a shell of the person remains, Joan Dayan argues: "The phantasm of the zombi - a soulless husk deprived of freedom - is the ultimate sign of loss and dispossession". ${ }^{35}$ Much earlier, the Swiss-American ethnologist Alfred Métraux argued that a "zombi's life is seen in terms that echo the harsh existence of a slave" in Saint-Domingue before the revolution. ${ }^{36}$ The Haitian author René Depestre does not only equate colonisation to a "process of man's general zombification" but he also identifies slavery as the origin of the zombie myth. Both zombies and slaves are robbed of their "spirit and reason"; they are reduced to their "labour power" alone. ${ }^{37}$

However pertinent the analogy slave/zombie may seem, it has its shortcomings. For enslaved persons - unlike most zombies - possess a consciousness and a will of their own, even if they are forcefully oppressed. These faculties are further the preconditions for slave resistance. Ubiquitous in all New World slave regimes, it stretched from everyday low-level resistance to full-scale slave revolts.

Given this repeated emphasis on the nexus between slaves and zombies, it is surprising that this figure scarcely appears in contemporary texts on the Haitian Revolution. When it 
does, then these zombie variants differ radically from the "enslaved" zombies described by William Seabrook, Alfred Métraux and René Depestre. ${ }^{38}$ One of the few mentions of the zombie as a supposedly undead person appears in the third volume of the Voyages d'un naturaliste (1809) by the French doctor and botanist Michel-Étienne Descourtilz, who temporarily was a prisoner of the black revolutionary army. He recounts the following uncanny anecdote. A soldier under the black general Toussaint Louverture meets his mother after a long period of separation; she is half-naked and marked by the ulcers and mental symptoms of venereal disease. She revives when she hears the name of her only son. ${ }^{39}$ However, he claims not to recognise her and calls her an old "zombie" wanting to deceive him. Full of loathing ("horreur"), he repulses her amid curses and insults. Besides the (perhaps feigned) revulsion of the son, the mother's behaviour and her skeletal body suggest her possible status as a zombie. When her son disowns her, she rolls around on the ground, bites the earth from which her body was possibly torn, and prays that death will come to her rescue. ${ }^{40}$

Has she lost her mind or is she a supernatural, undead being, a zombie? The text does not resolve this tension. Moreover, the narrator endeavours to gloss over this ambiguity by refusing to even consider a supernatural explanation. His sceptical attitude and his subsequent report to General Toussaint Louverture, who then punishes the soldier, show that he clearly considers this "zombie" to be an invention of the ungrateful son. Hence the explanation that the zombie is a "haunting spirit" persecuting the son that some critics have favoured remains unconvincing. ${ }^{41}$ For a spirit, Descourtilz places too much emphasis on the old woman's raw physicality, stressing her emaciated, cadaverous body "covered in ulcers". ${ }^{42}$ He seems to construe a racialised dichotomy between French/European Enlightenment on the one hand and Haitian/African, superstitions and beliefs on the other, such as "the West African shape-shifting duppy". ${ }^{43}$ However, Toussaint Louverture's "enlightened" dismissal of the supernatural zombie interpretation slightly subverts such a binary and lessens its uncanniness. To sum up, this episode remains cryptic, ambiguous and unresolved. While the narrator presents this event as a medical case, the soldier in the black army sees it as a case of witchcraft.

Perhaps a link to the zombie as a metaphor for disenfranchised slaves can be found in the old woman's past history, although we can only speculate on this. Is the woman the victim of a slave owner, who infected her with the venereal disease whose ulcers have disfigured her body and which has broken her mind? As for instance the early Haitian writer Baron de Vastey in his trenchant attack on slavery and colonialism Le système colonial dévoilé "[The Colonial System Unveiled]" (1814) asserts, sexual assaults and violence were endemic: "Haytian women were at the mercy of these lewd men, who abused them in the most horrific manner imaginable" ${ }^{44}$ The female "zombie" would then become a figure embodying the horrors of slavery, in particular the sexual exploitation of female slaves. In this case, the zombie would stand for the still fresh terror of a society built upon slavery which had been a "régime of calculated brutality and terrorism". 45

Further scattered texts exists in which the zombie and the Haitian Revolution are directly associated: yet, the reference to a "zombie" in the third volume of the Haitian mixed-race historian Thomas Madiou's Histoire d'Haiti (1848) does not deal with a zombie as the walking dead, but with a cold-blooded and brutal human being of mixed race. Madiou uses this figure to engage with the dominant, demonising discourse on the Haitian Revolution: in 1804, shortly after Haiti's independence, Governor-General Des- 
salines ordered the massacre of the majority of the remaining French inhabitants in revenge for the French generals' massacre of the civilian population and probably also because he was afraid of French conspiracies. ${ }^{46}$ According to Madiou, a "mulatto" called "Jean Zombi" distinguished himself through his particular "brutality". His outward appearance, with "red hair", "crazy eyes" and a "repulsive visage" ("figure ignoble"), reflects his suspect nature. ${ }^{47}$ Zombi stripped his white prisoner, dragged him up the stairs of the governor's palace and there stabbed him in the chest with a dagger. This barbaric act horrified all present, even the hardened former general Dessalines, who was infamous for his most likely apocryphal battle cry "Koupe tèt, brule kay" ("Cut off their heads, burn their houses.") ${ }^{48}$ As the author implies, his revulsion over this act shows his humanity, the "good heart" nurtured by "good instincts" that Dessalines displayed despite his cruelty towards the whites. ${ }^{49}$ While Madiou does not suggest in the slightest that Jean Zombi is undead, his brutality is still shown as unnatural and inhuman. His cold-blooded act of murder is a counterpart to the many examples of the Haitians' mercy that Madiou lists in his descriptions of the massacres.

His cruel deed has not prevented Jean Zombi from becoming part of the vodou canon. Not only does Jean Zombi stand for a cross between human and spirit in the trance of the vodou ritual, but - as Joan Dayan claims in a romantic interpretation - his ethnic hybridity also embodies the multi-ethnic dimension of the Haitians' struggle for freedom: "the intertwining of black and yellow, African and Creole in the struggle for independence". 50 Jean Zombi's later transformation into an important vodou deity or lwa, which Dayan points out, does not alter the fact that Madiou casts him as a brutal butcher rather than an ethnically hybrid revolutionary or freedom fighter.

In Madiou's text, elements of the malevolent North Atlantic demonisation to which the black Haitians were exposed, are projected onto the figure of Zombi. In these massacres of the remaining white French in Haiti, the mulatto Zombi takes the side of the blacks and acts more brutally than any of them. Madiou attributes exceptional cruelty only to some individual figures such as Zombi rather than the Haitian leaders and rank and file; in doing so, he is consciously writing against the demonising North Atlantic hegemonic discourse since the revolution.

As a massive violation of the "sanctity of whiteness", ${ }^{1}$ the massacres have been a central rallying point for racists for centuries. Through the massacres Haiti was "[s]ecuring [its] freedom in an orgy of white blood", as the historian Philippe Girard alleges, a stark foreshadowing of Haiti's purportedly savage "black" history: "dark as the tropical night, its violence rarely matched in the annals of human history". ${ }^{52}$ Dessalines' massacres, whose extent is controversial, marked a violent and clear break with centuries of colonialism. They also provided a prime opportunity for Haiti's racist detractors to find proof of the allegedly innate savagery of Haiti's black and their incapability to self-govern. Haitian revolutionaries have often been represented "an assemblage of all what was mean, and savage, and diabolical" as the British missionary and physician to the Haitian King Christophe William Harvey blackens Baron de Vastey's reputation in $1827 .^{53}$ In the same vein, Arthur J. Burks, US pulp fiction writer and former Marine during the US occupation of Haiti, regards Haiti's revolutionary leaders as "a line of ruling monsters such as may not be found in the history of any other country". ${ }^{4}$

As these examples demonstrate, casting the Haitian revolutionaries as savage Gothic 
monsters has been ripe in North Atlantic discourse. By contrast, the zombie only plays a subordinate role in texts on the Haitian Revolution (and on Haiti) in the eighteenth and nineteenth centuries, and in the case of Madiou, even figures to de-demonise the Haitian Revolution. Furthermore, in these texts the zombie is only associated with horror to a limited extent. Even at the end of the nineteenth century, tropes of horror such as cannibalism and voodoo were far more common than the zombie. For instance, even the arch-detractor of Haiti, British diplomat Sir Spenser St. John in a sensational and racist account Hayti, or the Black Republic (1884/1889) only mentions the zombie once and only in the sense of fantastic ghost. When he alleges that the Haitians "have much superstition with regard to zombis, revenants, or ghosts", 55 this claim seems directly copied from the Enlightenment proslavery writer Médéric Louis Élie Moreau de Saint-Méry, who had poked fun at the superstitious slaves who believed in the zombi as a kind of "ghost, revenant" (“esprit, revenant"). ${ }^{56}$ While St. John's gratuitous racist phantasies seminally contributed to shaping the North Atlantic narrative of Haiti as a land of savage horrors, the figure of the zombie is conspicuously absent in his phantasmagoria of evil. Instead, in the infamous chapter on "Vaudoux-Worship and Cannibalism" (extended for the second edition due to popular demand), he indulges in horror visions of cannibalism, as he claims that "goats without horns" - that is, human beings - are regularly sacrificed and eaten in the voodoo rituals. $^{57}$ He voyeuristically describes this in detail, down to the dishes supposedly cooked from the sacrificed children and Afro-Caribbean ingredients such as "Congo beans" and "yams". 58

As most critics concur, it was only the US occupation of Haiti (1915-1934) and its brutal forced labour regime that produced the horror figure of the modern zombie as a labouring undead person controlled by another in North Atlantic texts and films. ${ }^{59}$ While this type of zombie had existed before in Haitian folklore, with the American writers it was employed to demonise Haiti. As a horror trope the zombie feeds the North Atlantic myth of Haitian exceptionalism, which cast it as a place that is "strange, peculiar, freakish, queer, bizarre". 60 As Hannah Durkin asserts the US occupation had even "exacerbated cultural myths of the island as a land of savagery and sorcery". 61 Those tales of zombies are often related to forced labour and, more or less directly, to the US occupation, but not (or at least not explicitly) to the Haitian Revolution. One exception is "Salt Is Not for Slaves" (1931), a pulp fiction story by G. W. Hutter (pseudonym for Garnett Weston). This narrative, which abounds with horror tropes (and an evident lack of historical knowledge), refers explicitly to the Haitian Revolution. The slave rebels, who in the drunken orgiastic celebration of their freedom purposely flout their master's order not to eat salt, are turned into zombies. As such, they embark upon a wild, terrifying march to their graves, which had already been prepared, and die there. This latter part of the story is clearly borrowed from Seabrook's zombie story in The Magic Island (1929), in which the zombies, who have eaten salt, also rush back frenetically to their open graves. As Markman Ellis emphasises, Weston's story constitutes a counter-revolutionary rewriting of the history of the Haitian Revolution. ${ }^{62}$ Instead of freeing themselves and their fellow slaves, the rebellious slaves are punished for their revolt, first by being turned into zombies and then by death. It seems problematic to consider it - as Sarah Juliet Lauro does - as a "zombie rebellion" of zombies/slaves, since it is only their revolt and their first taste of freedom - symbolised by the tabooed eating of salt - that seems to turn them into the living dead. The simple moral, 
which refers equally to colonialism and slavery and to forced labour and neo-colonialism during the US occupation, is: "obeying the master [...] keeps you well and strong" ${ }^{63}$ The horrific figure of the zombie is meant to prevent workers/slaves from rebelling against their masters by equating the anti-colonial revolution with zombification, terror and death. In this revisionist story the Haitian Revolution serves as a cautionary tale. When Weston recasts this event not as a narrative of liberation from slavery and colonialism but one of renewed bondage and death, the zombie becomes an evil figure of transgression, which serves as a stark warning to refrain from any resistance: dare to overthrow the hegemonic (neo)-colonial Atlantic order and a punishment worse than death will be meted out to you. The zombie functions as a deeply counter-revolutionary horror trope that demonises both the slave agency during the Haitian Revolution and resistance against the US occupation.

\section{Counter-revolutionary zombies in Madison Smartt Bell's Haitian Trilogy}

Such counter-revolutionary uses of the zombie trope are not limited to cultural products of the US occupation but can even be found in present-day fiction. In contrast to the relative absence of zombies in discourse and histories on the Haitian Revolution, the epic trilogy of historical novels on the Haitian Revolution (1995-2004) by the US author Madison Smartt Bell is teeming with them. Even though some of these zombies follow the horror model established by the US cultural industry, undead persons controlled by others, Bell also harks back to older notions of the zombie.

One of Bell's characters is of mixed-race, with "piebald skin" and freckles, and who goes by the degrading name of Choufleur (cauliflower) ${ }^{64} \mathrm{He}$ is the illegitimate son of a wealthy aristocrat who refuses to acknowledge him. At one point Choufleur appears to the mixed-race prostitute Nanon in the trilogy's first novel All Souls' Rising (1995) as a zombie, in Moreau de Saint-Méry's sense of the word, that is, as a ghost:

She saw his image in one mirror but it was not repeated in the other, so that it seemed to her that he must be a ghost, or zombi, though she knew the illusion was only because of the angles at which they were standing. ${ }^{65}$

Even though this supernatural element immediately finds a rational resolution, Nanon's intuition proves prophetic. Invoking the trope of the mirror both revealing and shifting one's identity, Choufleur's identity changes from the denotation of zombi as ghost to that of sadistic torturer, as he displays inhuman cruelty on the day he murders his white, aristocratic father. This murder eclipses even the brutal execution of the white man by Jean Zombi ${ }^{66}$ Choufleur is a Jean Zombi seen through the lens of the horror movie: in a manner reminiscent of "slasher" films, he not only strips his victim, but flays him alive before progressing, seemingly unmoved, to other barbaric unquotable acts of perverse sadism. Choufleur even outdoes the sadistic slave rebel leader Jeannot who drinks the blood of his white victims out of a skull complete with scalp and hair and invents ever more depraved methods of torture and execution. While Bell's "racist stereotyping" portrays the slave rebels as racially othered Gothic monsters resembling "a collection of Tolkien's orcs on the rampage rather than human beings", with the character of Choufleur Bell also taps into the racist trope of the "evil mulatto", which Madiou's Jean Zombi also epitomises. ${ }^{67}$ The witness of this vicious execution, a medical doctor, feels 
"nausea" and "terror", but no pity, only a certain medical and metaphysical fascination. ${ }^{68}$ Eventually, he even experiences a kind of epiphany and realises "what it mean[s] to be human". ${ }^{69}$ Here, Bell glosses over an extremely brutal scene of torture and murder as an ontological experiment that lays bare the essence of human existence. Far more cold-blooded than his model Jean Zombi, Choufleur struggles with lack of emotion and unbelievable brutality in the "three-way genocidal race war" between gens de couleur, whites and black (ex-) slaves that Bell reduces the Haitian Revolution to in his trilogy. ${ }^{70}$ While Madiou "invented" Jean Zombi to de-demonise Dessalines and the Haitian revolutionaries, with his reiteration of the Jean Zombi Bell achieves exactly the opposite. Bell's excessive use of horror clichés, which he even heightens in his depraved phantasies, means that he even surpasses the racist, demonising and pornographic discourse of his source texts. ${ }^{71}$

Since the influence of pulp fiction and B "splatter" movies pervade Bell's trilogy, ${ }^{72}$ it comes as little surprise that it also features the figure of the zombie as the slaving undead controlled by an evil master. Despite his liberal use of Haitian creole terms, with his zombies he draws more on the Hollywood zombie tradition than any Haitian folklore sources. Bell's Georges Biassou, a major leader of the slave revolt of 1791 that set the Haitian Revolution in motion, doubles at night as a zombiemeister. It is conceivable that Bell partly here recalls a film character, another political zombiemeister Dargent Peytraud. In Wes Craven's zombie horror shocker The Serpent and the Rainbow (1988) Peytraud similarly doubles as the head of the tontons macoutes, the terror force of the Duvalier dictators. However, the influence of Craven's inspiration, Wade Davis' 1985 eponymous sensationalist travelogue, can also be discerned, when Biassou follows Wade's "recipe" for zombification and uses the dried "insides of a puffer fish" as one of the ingredients of his zombie paste. ${ }^{73}$ In his quest for the zombie poison, which is driven by his "infatuation with primitivism", Wade controversially suggests that the neurotoxin of this fish constitutes a major active component of the zombie poison. ${ }^{74}$ As he triumphantly claims, he has discovered "the material basis for the entire zombie phenomenon - a folk poison containing known toxins fully capable of pharmacologically inducing the state of apparent death". ${ }^{75}$

Bell's depiction is similarly sensationalist. Highly ironically for the leader of a slave revolt, Biassou creates his zombies for the sole purpose of using them as slaves. With Bell gratuitous violence lurks around every corner as his Biassou brutally beats a newly created zombie until his cudgel breaks. While the fictitious rebel slave Riau, who is one of Bell's narrators, assumes that Biassou must have killed the undead man a second time, the zombie rises again at his master's behest in true horror movie fashion: "But when Biassou commanded it to get up, the zombi rose once more. It stood with its head swinging and its two arms hanging down" ${ }^{76}$ The zombie slave proves to be both more obedient and hardy than the human slaves, who were often beaten to death by their owners. The zombification acquires even more sinister overtones as it is a fellow slave rebel, Chacha, whom Biassou re-enslaves as his zombie.

Bell seems to draw on a diverse range of models for his depiction of the zombie as the ideal slave, including Seabrook's The Magic Island. Seabrook's text not only contains a reference to a zombie being made a "servant or slave" by a sorcerer, but it also retells a story about an evil sorcerer zombifying and enslaving "nine dead men and women" to work for an US American sugar conglomerate. ${ }^{77}$ Bell seems to echo Seabrook, as his 
Biassou also runs a zombie and slave enterprise within a proto-industrial context but on a far grander scale. In the novel, rumours circulate about the existence of a veritable zombie slave farm, "where Biassou had fields of zombis that must work for him" ${ }^{78}$ In the second part of the trilogy, Riau does actually discover a zombie farm of this kind. In his quasi-divine role, in which all around him regard as "Bon Dyé", the highest, unattainable deity in vodou, Riau uses salt to bring the zombies back to life. This revival of the undead stands in contrast to Seabrook's and Weston's narratives, in which the eating of salt makes the zombies aware of their dead state and causes the "walking corpses" to flee to their graves. ${ }^{79}$

After Riau has shot the zombie master, he is confronted with the question of how successful his liberation of the slaves and zombies really has been:

\begin{abstract}
Now the zombis were all moving aimlessly around like ants do when one has kicked over the hill. Everything rushed up at me, swooping as in my dream, this zombi farm and the barracoon and the slave ship still waiting on the beach and the men in the tobacco who scarcely cared if they were free and Moyse's death bound soon to come and all the people across the border working quietly, tightly, under Toussaint's order. All this at once, and the same voice in my ear, but now the words were different. What they did to us, we have learned to do to ourselves. Where would it end? There could be no end. ${ }^{80}$
\end{abstract}

The emancipation of the zombies/slaves from "above" seems to have largely clearly failed. On the one hand, this passage appears to postulate a kind of psychopathology of slavery that simultaneously functions as an apologia for the trilogy's excessive, seemingly endless orgies of violence. On the other hand, here Riau seems to enquire into the distinction between slavery, zombie labour and "free" labour, noting that the differences are often gradual and that nearly all workers are affected by exploitation and violence. However, in doing so he also glosses over differences between the newly liberated, zombie-like (as is implied) slaves working in the invaded Spanish colony of Santo Domingo, who do not seem to cherish their freedom, the actual zombies and finally the 'free' cultivateurs in Saint-Domingue. Using General Moyse as their figurehead, these ex-slaves revolted against the militaristic and exploitative plantation regime that Toussaint had imposed on them. Contrary what Bell wants to make us believe, not all slaves/labourers/zombies were the same and the difference lies in their agency and their will to resist and struggle for freedom: key distinctions that Bell blurs.

The precarious doubling of zombies and slaves runs through Smartt Bell's entire trilogy. In the first volume, Riau thus dreams of slaves on a plantation who are all zombies, and recalls that he was reduced to his "corps-cadavre", his mere physicality, like a zombie, not only on the slave ship but during his entire time as a slave. ${ }^{81}$ Analogously to Orlando Patterson's theory of slavery as "social death", Riau declares that Toussaint taught him how to endure this zombie-esque, death-like existence as a slave: "Toussaint taught me how to be a slave, how to bear my death". 82 As Patterson highlights, a slave is not only "desocialized", but also - like the zombie - "depersonalized" ${ }^{83}$

However, through their agency slaves (who unlike zombies had a consciousness) could mitigate or, in rare instances, even overcome this state. As pointed out earlier, this fundamental distinction between slave and zombie has been frequently overlooked in the both criticism and works of literature and non-fiction. Two years before Bell, the British travel writer Ian Thomson in his lurid travelogue of Haiti Bonjour Blanc (1992) interviews a 
"real-life" zombie, Clairvivus Narcisse. Although allegedly without consciousness as a zombie, Narcisse surprisingly tells of a burgeoning zombie industry in Haiti, when he recounts how he "he lived in a large hangar with hundred and fifty other zombis, nine of whom were women". ${ }^{84}$ Similar to Bell, Thomson links zombification to re-enslavement and to the failures of the Haitian Revolution to brie freedom Revived or galvaanized into movement within three days of his entombment, Narcisse was set to work as a zombi in a large field weeding and planting. He worked ferociously and tirelessly for his master, a pitiful drudge without consciousness of his surroundings. This may explain why zombification is the most terrible of curses: it represents a return to the slavery that Tous- saint L'Ouverture had abolished [sic]. Narcisse was sold - "vendu" - as a zombi by his two brothers. ${ }^{85}$

Thomson seems to imply the revolutionary emancipation of the slaves has failed since allegedly zombies are being exploited today as unpaid labour and even sold like slaves were in the past.

As with Bell also here zombification of the slaves endlessly replicates the dehumanising violence against slaves. It is one link in a chain of endless racial violence that - in Bell's account - the Haitian Revolution has been unable to overcome. On the contrary, the excessive and pornographic depiction of extreme violence throughout his trilogy suggests that the revolution has unleashed a vicious cycle of violence, compared to which the violence and the terror of plantation slavery almost pale. His trilogy's narrative thus constitutes a revisionist and ultimately counter-revolutionary history of the Haitian Revolution in which neither racial violence nor slavery has ultimately been overcome. The zombie marks one of the countless tropes of horror that demonise the slave rebel in Bell's novels including the infamous, apocryphal impaled white infant and white prisoners hung on meat hooks. Within Bell's Haitian Gothic the zombie functions as a key weapon in Bell's arsenal of horror tropes that he deploys to demonise people of colour, portraying them alternately as bloodthirsty savages, practitioners of black magic, sex objects or sadist torturers of white people.

\section{Beyond the horror trope? The zombie, alienation and exploitation}

Whereas I have so far mainly dealt with the zombie as a reactionary and demonising trope of the Haitian Gothic, in this final section I want to go beyond the zombie as a mere horror trope. Rather than affirming the neo-colonial, capitalist status quo, could the zombie also harbour a critical potential that might subvert the North Atlantic hegemonic order?

We can see some of such subversive potential in Seabrook's The Magic Island (1929), which "was to disseminate the image of the zombie outside Haiti". ${ }^{86}$ When he presses his Haitian informant Constant Polynice for a zombie tale, Seabrook gets more than he has bargained for. The tale about an alleged event in 1918 tells of group of enslaved zombies who tirelessly "slave" on "distant fields". ${ }^{87}$ While they were allegedly zombified and enslaved by the Haitian "old black headman, Ti Joseph", the fields belong to the American conglomerate HASCO (Haitian American Sugar Company). ${ }^{88}$ It exploits its workers as wage slaves in a neo-colonial manner, as it promises steady employment at exploitative pay: it "pays low wages [...] and gives steady work". 89 Seabrook is outraged that the zombies should toil for HASCO. "[L]ike a chunk of Hoboken", as "a modern big business", this global conglomerate constitutes the exact antithesis to his view of Haiti as the 
epitome of primitiveness. ${ }^{90}$ For Seabrook the zombie serves as a key marker of Haiti's gothicised and exoticised exceptionalism. When he contends that "I have never ever, except in Haiti, heard of anything like zombies" he perpetuates - what Michel-Rolph Trouillot has termed - the myth of Haitian exceptionalism. Haiti is constructed as "unique, bizarre, unnatural, odd, queer, freakish, or grotesque", a pervasive cliché of Haiti to which the zombie has significantly contributed. ${ }^{91}$ Hence, Seabrook is appalled when the figure of the zombie is associated not with some pre-modern savage primitivism but instead with modern industrialist US sugar production. For him modern US capitalism serves as "an incongruous background for this weird tale" of zombies. ${ }^{92}$ From a narrative and ideological point of view this episode is complex: the tale within the tale is purportedly told by a Haitian to a US American writer during the US occupation. Sarah Juliet Lauro claims that this narrative "implicates global capitalism from the very beginning of American interest in the zombie". ${ }^{93}$ But who does the implicating? Polynice's mediated voice or Seabrook? I would argue that the naïve American Seabrook fails to recognise how his Haitian informant Constant Polynice tells him a parable about neo-colonialist exploitation of Haitians under the US occupation packaged as a sensationalist zombie tale. Kate Ramsey suggests that Polynice's tale about HASCO and sorcery in US-occupied Haiti may not have been unique: "As the largest American-owned enterprise in Haiti and foremost icon of the agribusiness that was steadily displacing peasant sharecroppers across these regions by means of land appropriations, HASCO was [...] a highly likely object of sorcery discourse". ${ }^{94}$ Neocolonialist practices collide with an anti-colonialist discourse that indicts the US capitalist appropriation of land as sorcery and zombification. HASCO's appropriations also mark an indirect assault on the Haitian Revolution and the subsequent "constitutional prohibition on foreign land ownership", which had been overturned by the US enforced 1918 constitution. $^{95}$

Moreover, unlike Seabrook, Polynice also seems to be aware that both the sugar mill and the figure of the zombie as exploited slave are products of modernity not primitive throwbacks. As C.L.R. James insists, plantation slavery with proto-industrial slavepowered "sugar-factories" created its own modern gravediggers: the slaves in SaintDomingue "were closer to a modern proletariat than any group of workers in existence at the time, and the [1791] rising was, therefore, a thoroughly prepared and organized mass movement". ${ }^{96}$

To sum up, working zombies of the kind encountered in Seabrook (if not in Bell) represent a metaphor not only for slaves but also for highly exploited workers in a neo-colonial context. Without levelling the difference between the two, in conclusion I want to consider if the figure of the zombie could have a function beyond the horror trope, as a trope for the hyper-exploited worker? As scholars have shown, both in other concrete instances of extreme exploitation, such as immigrant workers in South Africa, and as a more abstract metaphor in anti-capitalist critique, the figure of the zombie has featured prominently. ${ }^{97}$

Already Marx's critique of capitalist alienated labour invites such metaphorical comparison between the proletarian and the zombie. As he emphasises in Critical Marginal Notes (1844), the exploited worker utterly alienated from him - or herself - is also undead in a way, as he is excluded from societal life:

This community [Gemeinwesen], from which his own labour separates him, is life itself, physical 
and intellectual life, human morality [Sittlichkeit], human activity, human enjoyment, human nature. Human nature is the true community of man. ${ }^{98}$

In his state of "social death" under capitalism Marx's proletarian resembles both the zombie and the slave. Industrial capitalism is the successor to the Atlantic slave economy that fuelled it and the proletarian resembles a slave in modern capitalist society, which for Marx constitutes but an advanced slave society. Private property, "this slavery of [bourgeois] [bürgerlichen] society", forms its fetters, and this form of slavery "is the natural basis on which the modern state rests". ${ }^{99}$

However, the worker alienated from his own human nature, and the slave as the symbolic zombie, as an "alienated man robbed of his will", ${ }^{100}$ differ in one key aspect from the undead zombie "[who] will work ferociously and tirelessly without consciousness of his surroundings and conditions". ${ }^{101}$ Unlike zombies without consciousness, as described by Seabrook and Bell, workers and slaves possess a - potentially revolutionary - consciousness. Without consciousness there can be no resistance, no agency, no revolt, let alone the Haitian Revolution. Thus the equation of slaves and zombies as figures without consciousness is both dehumanising and counter-revolutionary. For despite all their degradation, their demonisation, their treatment as animals and chattel, as property, slaves remained "invincibly human beings", a resilience that James regards as the precondition for the Haitian Revolution. ${ }^{102}$

(Self-) consciousness is as essential for asserting this proto-revolutionary humanity and for slave revolt and revolution as it as for proletarian revolution. In Grundrisse (1857-1861), Marx draws a parallel between the dawning consciousness of the proletarian that the mode of production alienates him from his rightful property, the produce of his labour, and the slave who realises that his status as property is the powerful legal fiction that perpetuates slavery. ${ }^{103}$ As he states, "the slave's awareness that he cannot be the property of another, with his consciousness of himself as a person" heralds the end of slavery as much as the corresponding proletarian insight that the produce of his labour is his own spells the eventual end to capitalism. ${ }^{104}$ Both are "the knell to its doom". ${ }^{105}$

Arguing within a Marxist framework, African American activist and scholar Angela Davis insists that chattel slavery is the "most extreme form of human alienation", not simply because of their extremely alienated and exploited labour, but also because they are reduced to commodities and capital. For to be a chattel slave means the "reduction to the status of property" ${ }^{106}$ As with Marx, awareness of this state marks a key step towards overcoming it by resistance: "Consciousness of alienation entails the absolute refusal to accept that alienation". ${ }^{107}$ Yet, less idealist than Marx and more aware of the enormous struggles to abolish slavery and fight its toxic legacies, Davis insists that alienation can only be overcome through the material abolition of slavery and its vestiges:

It is only with the total abolition of the institution of slavery that his misery, his desolation, his alienation will be eliminated. And not even then, for there will remain remnants and there still remain in existence today the causes that gave rise to slavery. ${ }^{108}$

Both Davis and Marx see gaining consciousness of the ideological fictions and material practices that sustain slavery as essential and regard this as a key revolutionary means to overcome slavery. However, precisely this proto-revolutionary consciousness is lacking in those zombies that are controlled by a sorcerer (bòkò) - as is for instance the case in Bell. They are 
not just the property of someone else, but even their entire consciousness is enslaved and controlled by their master. This fundamental difference in consciousness between hyperexploited, alienated labourer/slave on the one hand, and zombie is frequently ignored in critical literature on the zombie. For instance, Kaiama L. Glover claims not only that the zombie forms a "[f]igure of exploitation par excellence" but also that in Haitian literature zombification is the specific Haitian variety of Marx's theory of alienation: "the concept of zombification effectively places the Marxist theory of alienation - victimization at the hands of an external agent - in a specifically Haitian context". ${ }^{109}$ Yet, only by depriving the proletarian of his proto-revolutionary consciousness, and thus the potential for resistance, is it possible to regard the zombie and the worker as equally victimised.

Analogously, the metaphor of the slave as zombie is similarly revisionist since it precludes the slave from acquiring an awareness of his conditions and thus deprives the enslaved of revolutionary agency. The Haitian Revolution represents one of the strongest expressions of the slaves' resistance to the attempt to dehumanise and depersonalise them. By contrast, the modern zombie, with its passivity, its heteronomy and its lack of consciousness, could even be seen as embodying the counter-revolutionary figure of the ideal slave. He or she is drudging mechanically and constantly, like a machine, devoid of any feelings, or any will to resist.

Such a phantasm of the ideal slave/zombie is hauntingly conjured up in a key scene in the first zombie movie White Zombie (1932). Its screenplay was written by Garnett Weston, author of the zombie pulp fiction tale "Salt Is Not Slaves", discussed earlier. In the film the absence of emotion and lack of resistance in the zombie becomes a prime source of terror. Both black-faced and white zombies are working as slaves and operating a circular, creaking two-tiered sugar mill feeding it from the top with sugar cane. When one of the zombies (significantly a black-faced one) loses its balance and falls into the grinder, the other zombies do not even flinch, let alone pause in their toil for even a fraction of a second.

While such accidents were not uncommon during plantation slavery, it is the utter lack of consciousness, emotion and resistance that marks these zombie machines as the ideal slaves, more easily replaceable, cheaper and more tractable than the real slaves, from the perspective of the slaveholder. As Bela Lugosi's zombie master Murder Legendre advertises his zombies to his neighbour: "They work faithfully. They do not complain about long hours. You, you, could make good use of my men on your plantation." These slaving zombies obviously echo Seabrook's zombies who slave in the fields for the Haitian American Sugar Company. Yet, the trenchant critique of imperialism and the US occupation that Seabrook's Haitian informant manages to smuggle into Seabrook's sensationalist zombie story is largely lacking in White Zombie. Unlike in The Magic Island, in White Zombie there is no mention of HASCO or any other American imperial companies exploiting Haitians during the US occupation, but Haiti epitomises a primitive pre-modernity in which a white sorcerer with a French name is the exploiter. ${ }^{110}$ This distinction seems to preclude any interpretation of the film as an anti-imperialist "nightmarish fantasy of American empire". 11

On the contrary, if the ideal unresisting, drudging (wage-) slave could be produced without resorting to Haitian, "savage", black magic, this would mark the ultimate triumph for American capitalism abroad as well as at home. While "Legendre's crew of shuffling, vacant-eyed zombies [present] the picture of alienated labour", they are - at 
the same time - grist to the US capitalists' mills. ${ }^{112}$ The American occupying forces in Haiti facing resistance, and the capitalists at home, who were facing labour protest, strikes and civil unrest at the height of the Great Depression, both would have been relieved of some major headaches would they have had such zombie workers.

While the zombie could function as vehicle for political satire, for instance to indict exploitation, it is in essence a deeply anti-revolutionary trope. In contrast to actual labourers and historical slaves, the zombie is incapable of offering resistance. Even when the zombie is liberated and brought back to life, this is not per se a revolutionary self-emancipation such as that of the slaves in Saint-Domingue, as, for instance, the reawakening scene in Bell's trilogy illustrates. Accordingly, this kind of zombie is incompatible with the figure of the slave revolutionary. This is also reflected in the low number of texts on the Haitian Revolution that deal with zombies. Even Moreau de Saint-Méry's revenant and Descourtilz's zombie mother are not revolutionary characters. And Madiou presents the horror emanating from Jean Zombi not as revolutionary terror, but as the terror spread by a mass murderer.

A revolutionary use of the figure of the zombie, beyond its function as a trope of terror, only works if its dezombification is simultaneously presented as overcoming its lack of consciousness, its reification and role as a victim and ultimately leads to resistance. As Rachel Douglas and Kaiama L. Glover point out, Haitian writer and painter Frankétienne depicts such a process in the first Haitian Creole novel Dézafi (1975) and even more pronouncedly, in his French rewriting Les Affres d'un défi (1979). In it dezombification leads to a regaining of consciousness of ex-zonbis who subsequently revolt against their exploiter and kill him. ${ }^{113}$ Significantly it is a Haitian and not a North Atlantic writer with whom the zonbi transcend its limitation to a mere horror trope. As Elizabeth MacAlister points out, in Haiti, "like the colonial slave, or the oppressed worker, zonbi also possess the potential for out-and-out rebellion". ${ }^{114}$ "Cap'tain Zombi" in Depestre's epic poem Un arc-en-ciel pour l'occident chrétien even becomes a figure of Black Atlantic revolutionary vengeance. ${ }^{115}$

By contrast, the North Atlantic figure of the zombie irredeemably shackled by his exploiter's total control risks merely reproducing the cliché of human beings of the African diaspora as passive victims in a further act of discursive violence. In this use, the zombie amounts to little more than a white racist revenge fantasy of re-enslavement and re-subjugation of black people. This seems the principal reason why the zombie has been claimed to originate in Haiti, which through its revolution has contributed majorly to dislodging slavery, colonialism and white supremacy.

Viewed from this angle the terror trope of the zombie forms just another weapon in the arsenal of the Haitian Gothic and its connected, concerted North Atlantic campaign to demonise Haiti, its history and its people. As Edward Kamau Braithwaite suggests, the zombie functions as one among many tropes of terror to demonise Haiti as America's African Heart of Darkness: Haiti has been portrayed as the "darkness of the night of ignorance, of voodoo drums and human sacrifice, of zombies, Congo gutturals". ${ }^{116}$ The zombie trope has formed such a powerful, often demonising, counter-revolutionary component of the North Atlantic discourse on Haiti that it might prove hard to salvage it for less nefarious or even emancipatory purposes. 


\section{Notes}

1. Trouillot, Silencing the Past, 95-107.

2. Aravamudan, Tropicopolitans: Colonialism and Agency, 292.

3. See, for instance, Nesbitt, Universal Emancipation; James, The Black Jacobins, 66; Hallward, Damming the Flood, 11 and "Haitian Inspiration"; Kaisary, The Haitian Revolution, 21-36. Blackburn, The American Crucible, 173-219. For a revisionist counter position that regards freedom and the Rights of Man as bestowed upon the slaves by the French Revolutionary Republic, see Popkin, You Are All Free. To discuss the universality of the Haitian Revolution's conception of rights would go far beyond the scope of this article.

4. See Singham, "Betwixt Cattle and Men" and Dubois, "Gendered Freedom".

5. Celucien Joseph was among the first to use this term. See The Haitian Turn. See Bandau, "Transatlantic Representations" for an overview and critique of the Haitian Turn and its heterogeneous studies. The most important among them are Trouillot, Silencing the Past; Dayan, Haiti, History, and the Gods; Fischer, Modernity Disavowed; Nesbitt, Universal Emancipation; Buck-Morss, Hegel, Haiti, and Universal History; and Miller, Elusive Origins.

6. Nesbitt, "Haiti, the Monstrous Anomaly," 3.

7. Ulysse, Why Haiti Needs New Narratives, 28.

8. Dash, Haiti and the United States, 3.

9. Hoermann, "A Very Hell of Horrors."

10. With "zombie" I refer to its often sensationalist uses in North Atlantic discourse, whereas "zonbi" relates to Haitian folklore and culture.

11. Laguerre, Voodoo and Politics, 19.

12. MacAlister, Rara!, n. 226. For anthropological engagements with the figure of the zonbi in Haitian religion and culture, see Herkovits, Life in a Haitian Valley, 248; Métraux, Voodoo in Haiti, 281-285; Ackerman and Gauthier, "The Ways and Nature"; and MacAlister, Rara!, 98111 and "Slaves, Cannibals," 462-469. For Haitian postcolonial writers and their use of the zonbi, see Douglas, Frankétienne and Rewriting and Glover, Haiti Unbound.

13. Ulysse, Why Haiti Needs New Narratives, 28

14. "Constitution Impériale," my translation.

15. Fischer, Modernity Disavowed, 223.

16. For the spectre of the Haitian Revolution in the Caribbean, see Munford and Zeuske, "Black Slavery, Class Struggle," 12-32. In the USA, see Clavin, Toussaint Louverture; White, Encountering Revolution; and Hunt, Haiti's Influence on Antebellum America.

17. Jefferson, "Letter to Aaron Burr," 161.

18. Dessalines and Chanlatte, Liberté ou la mort. My translation. See Hoermann, "A Very Hell of Horrors," 196.

19. A Particular Account, 3.

20. Douglass, "From a Lecture on Haiti," 206.

21. Paravisini-Gebert, "Colonial and Postcolonial Gothic," 234.

22. Chomsky, "Introduction," 15. On the atrocious media coverage of Haiti from the eighteenth to the twentieth century, see Lawless, Haiti's Bad Press.

23. See Hoermann, "A Very Hell of Horrors." Nzengou-Tayo, "Haitian Gothic and History" also uses the term "Haitian Gothic" in her title of article on Madison Smart Bell's Haitian Trilogy, albeit without defining or reflecting upon it further.

24. Seitenfus, "Haiti est la preuve." My translation.

25. Ulysse, Why Haiti Needs New Narratives, 28.

26. See Wood, The Horrible Gift.

27. Fanon, Black Skin, White Masks, 195.

28. Douglass "From a Lecture on Haiti," 210. Italics in original.

29. Fanon, Black Skin, White Masks, 194. Italics in original.

30. Mintz, "Whitewashing Haiti's History." Italics in original.

31. Huxley, The Invisibles, 9. 
32. Seabrook, The Magic Island, 94.

33. Herskovits, Life in a Haitian Valley, 248. Hurston, Tell My Horse, 182-183.

34. Ibid., 180. The photograph first appeared under the name of Hurston's photographer Hardy Rex Jr. in 1937 in Life Magazine billed as the "first photograph of a zombie ever taken" (King and Rex, Black Haiti, 27); a claim reiterated by Hurston not only in her study but also in a 1943 radio interview (see Faircloth, "Zora Neale Hurston"). As early as 1945 a Haitian professor of psychiatry Dr Louis P. Mars, who had treated Mentor for "schizophrenia", doubted Hurston's assertion and accused her of having abandoned science in favour of the "popular belief of the Zombi pseudo-science" ("The Story of Zombi," 39).

35. Dayan, Haiti, History and the Gods, 37.

36. Métraux, Voodoo in Haiti, 282.

37. Cited in Laroche, "The Myth of the Zombi," 59. My translation.

38. Ackerman and Gauthier distinguish two main categories of zombie, "body without soul" and "soul without body", as well as a great number of sub-categories, which nevertheless fail to cover all of the sub-species of zombie discussed here. Ackerman and Gauthier, "The Ways and Nature," 476-477.

39. Descourtilz, Voyages d'un naturaliste, 220.

40. Ibid.

41. Murphy, "White Zombie," 50.

42. Descourtilz, Voyages d'un naturaliste, 219.

43. Lauro, The Transatlantic Zombie, 42.

44. Vastey, The Colonial System Unveiled, 127.

45. James, The Black Jacobins, 9.

46. Dubois, Avengers, 299-300.

47. Madiou, Histoire d'Haït (1848), 133.

48. In spite of scarce historical evidence for this slogan, it has been cited as fact by scholars, for example. Dayan, Haiti, History, and the Gods, 20 and Bell, Toussaint Louverture, 289. Despite its dubious historical authenticity, "it has endured in the collective memory". Sourieau, "Dessalines in Historic Drama", 28.

49. Madiou, Histoire d'Haïti (1848), 123.

50. Dayan, Haiti, History, and the Gods, 36.

51. Ulysse, Why Haiti Needs New Narratives, 28.

52. Girard, Haiti: The Tumultuous History, 61, 9.

53. Harvey, Sketches of Hayti, 224.

54. Burks, Black Medicine, 137.

55. St. John, Hayti, or the Black Republic, 164.

56. Moreau de Saint-Méry, Description topographique, 52.

57. Ibid., 191-192.

58. Ibid., 213.

59. Dayan, Haiti, History, and the Gods, 37-38; Ellis, The History of Gothic Fiction, 118-120; Sheller, Consuming the Caribbean, 145-146.

60. Trouillot, "The Odd and the Ordinary," 6.

61. Durkin, "The Greatest Monuments on Earth," 189.

62. Ellis, The History of Gothic Fiction, 229.

63. Hutter, "Salt Is Not for Slaves," 381

64. Bell, All Souls' Rising, 80. On racist theories and fears associated with persons of mixed ethnicity and their unusual skin colour (including piebald skin) in texts of Buffon, Moreau de Saint-Méry and other contemporary authors, see Dayan, Haiti, History, and the Gods, 237-242.

65. Ibid., 132.

66. Bell, Master of the Crossroads, 69.

67. Kaisary, The Haitian Revolution, 166. Both Jean Zonbi and Choufleur also conform to ambiguous "racial trope" of "monstrous hybridity" in discourse on the Haitian Revolution. See Daut, 
Tropics of Haiti, 73-194.

68. Bell, Master of the Crossroads, 69.

69. Bell, All Souls' Rising, 237.

70. Bell, Toussaint Louverture, 22.

71. For Bell's erotic/pornographic racism, see Kaisary, The Haitian Revolution, 157-169.

72. See ibid., 161, 166.

73. Bell, All Souls' Rising, 473.

74. Dash, Haiti and the United States, 143.

75. Wade, The Serpent, 126.

76. Bell, All Souls' Rising, 475.

77. Seabrook, The Magic Island, 94, 96-97.

78. Bell, All Souls' Rising, 475.

79. Seabrook, The Magic Island, 99-100.

80. Bell, Master of the Crossroads, 650. Italics in the original text.

81. Bell, All Souls' Rising, 471, 476.

82. Ibid., 476.

83. Patterson, Slavery and Social Death, 38.

84. Thomson, "Bonjour Blanc," 273.

85. Ibid., 272.

86. Dalleo, American Imperialism's Undead, 182. Dalleo also presents a graph that shows how the publication of Seabrook's travelogue in 1929 exponentially increased the use of the word "zombie" in English (ibid.).

87. Seabrook, The Magic Island, 96.

88. Ibid.

89. Ibid.

90. Ibid., 95-96.

91. Trouillot, "The Odd and the Ordinary," 6.

92. Seabrook, The Magic Island, 96.

93. Lauro, The Transatlantic Zombie, 79.

94. Ramsey, The Spirits and the Law, 173.

95. Renda, Taking Haiti, 31.

96. James, The Black Jacobins, 69.

97. See Comaroff and Comaroff, "Alien-Nations," Ehrmann, "Walking Debt."

98. Marx, Early Political Writings, 113. Emphasis in original.

99. Ibid., 106 .

100. Laroche, "The Myth of the Zombi," 55.

101. Hurston, Tell My Horse, 183. Emphasis added by the author.

102. James, The Black Jacobins, 9.

103. Marx, Grundrisse.

104. Ibid., 463. Italics in the original text.

105. Ibid.

106. Davis, "Lectures on Liberation," 53.

107. Ibid., 58 .

108. Ibid., 59. Emphasis in original text.

109. Glover, Haiti Unbound, 58.

110. It seems factually inaccurate to contend that both "the zombies described by Seabrook and those at the beginning of White Zombie were explicitly victims of the proletarianization of Haitian peasants by multinational corporations like the Haitian American Sugar Company." Dalleo, American Imperialism's Undead, 183.

111. Fay, "Dead Subjectivity," 85.

112. Ramsey, The Spirits and the Law, 172.

113. Glover, Haiti Unbound, 60-61; Douglas, Frankétienne and Rewriting, 44-46.

114. MacAlister, "Slaves, Cannibals," 468.

115. Depestre, A Rainbow, 146-149. 
116. Braithwaite, "Introduction," xii.

\section{Acknowledgements}

I am grateful to Dr Margaret Hiley, Nicolas Tate and Jasleen Kaur for proofreading and editorial services. I am indebted to the two anonymous peer-reviewers for providing astute comments and pointing out further seminal criticism. I am also grateful to the editor Dr Dorothea FischerHornung for her very thorough editing.

\section{Disclosure statement}

No potential conflict of interest was reported by the author.

\section{Funding}

This research was partly supported by a Marie Curie Intra-European Fellowship by the European Commission's Seventh Framework Programme [grant number PIEF-GA-2013-629486 - Goth-NarHaitian-Rev].

\section{Notes on contributor}

Dr Raphael Hoermann is currently Senior Research Fellow with the Institute for Black Atlantic Research (IBAR) at the University of Central Lancashire.

\section{ORCID}

Raphael Hoermann ihttp://orcid.org/0000-0001-6156-8431

\section{References}

Ackermann, Hans W., and Jeanine Gauthier. "The Ways and Nature of the Zombi." The Journal of American Folklore 104, no. 114 (1991): 466-494.

Aravamudan, Srinivas. Tropicopolitans: Colonialism and Agency, 1688-1804. Durham, NC: Duke University Press, 1999.

Bandau, Anja. "Transatlantic Representations of the Revolution in Saint-Domingue at the End of the Eighteenth Century and the Haitian Turn.” In Postcolonial Studies Across the Disciplines, edited by Jana Gohrisch and Ellen Grünkemeier, 187-207. Amsterdam: Rodopi, 2013.

Bell, Madison Smartt. All Souls' Rising. London: Granta Books, 1995.

Bell, Madison Smartt. Master of the Crossroads. New York: Vintage, 2000.

Bell, Madison Smartt. Toussaint Louverture. A Biography. New York: Vintage, 2008.

Blackburn, Robin. The American Crucible: Slavery, Emancipation and Human Rights. London: Verso, 2011.

Braithwaite, Edward Kamau. "Introduction." In Life in a Haitian Valley, edited by Melville J. Herskovits, v-xviii. Garden City, NY: Doubleday, 1971.

Buck-Morss, Susan. Hegel, Haiti, and Universal History. Pittsburgh, PA: University of Pittsburgh Press, 2009.

Burks, Arthur J. Black Medicine. Sauk City, WI: Arkham House, 1969.

Chomsky, Noam. "Introduction." In The Uses of Haiti, edited by Paul Farmer, 15-40. Monroe: Common Courage Press, 1994.

Clavin, Matthew J. Toussaint Louverture and the American Civil War: The Promise and Peril of a Second Haitian Revolution. Philadelphia: University of Pennsylvania Press, 2010.

Comaroff, Jean, and John L. Comaroff. "Alien-Nation: Zombies, Immigrants, and Millennial Capitalism," The South Atlantic Quarterly 101, no. 4 (2002): 779-805. 
Dalleo, Raphael. American Imperialism's Undead: The Occupation of Haiti and the Rise of Caribbean Anticolonialism. Charlottesville: University of Virginia Press, 2016.

Dash, Michael J. Haiti and the United States: National Stereotypes and the Literary Imagination. 2nd ed. New York: Palgrave Macmillan, 1997.

Daut, Marlene L. Tropics of Haiti: Race and the Literary History of the Haitian in the Atlantic World. Liverpool: Liverpool University Press, 2015.

Davis, Angela Y. "Lectures on Liberation." In Narrative of the Life of Frederick Douglass, an American Slave, Written by Himself, edit1995chuster, 1985.

Dayan, Joan. Haiti, History, and the Gods. Berkeley: University of California Press,

Depestre, René. A Rainbow for the Christian West. Translated by Joan Dayan. Amherst: University of Massachusetts Press, 1977.

Descourtilz, Michel-Étienne. Voyages d'un naturaliste, et ses observations [...], Vol. 3. Paris: Dufat, 1809.

Dessalines, Jean-Jacques, and Juste Chanlatte. Liberté ou la mort: Proclamation. Jean-Jacques Dessalines, Gouverneur Général aux habitans d'Haïti (28 April 1804). Accessed 20 January 2015. https://haitiandeclarationofindependence.files.wordpress.com/2013/08/dscf9464.jpg.

Douglas, Rachel. Frankétienne and Rewriting: A Work in Progress. Lanham, MD: Lexington Books, 2009.

Douglass, Frederick. "From a Lecture on Haiti [ ... ]." In African Americans and the Haitian Revolutions: Selected Essays and Historical Documents, edited by Maurice Jackson and Jacqueline Bacon, 202211. New York: Routledge, 2010.

Dubois, Laurent. Avengers of the New World: The Story of the Haitian Revolution. Cambridge, MA: Belknap Press of Harvard University Press, 2004.

Dubois, Laurent. "Gendered Freedom: Citoyennes and War in the Revolutionary French Caribbean." In Gender, War and Politics: Transatlantic Perspectives, 1775-1830, edited by Karen Hagemann, Gisela Metelle, and Jane Rendall, 58-70, Houndmills, UK: Palgrave Macmillan, 2010.

Durkin, Hannah. "The Greatest Monuments on Earth': Richmond Barthé's Memorials to Toussaint Louverture and Jean-Jacques Dessalines." In Visualising Slavery: Art Across the African Diaspora, edited by Celeste-Marie Bernier and Hannah Durkin, 184-200. Liverpool: Liverpool University Press, 2016.

Ehrmann, Jeanette. "Working Dead, Walking Debt. Der Zombie als Metapher der Kapitalismuskritik." Zeitschrift für Kulturwissenschaft 1 (2014): 21-34.

Ellis, Markman. The History of Gothic Fiction. Edinburgh: Edinburgh University Press, 2000.

Faircloth, Kelly. "Zora Neale Hurston, Zombie Hunter." Accessed 16 September 2016. http://io9. gizmodo.com/5823671/zora-neale-hurston-zombie-hunter.

Fanon, Frantz. Black Skin, White Masks. Translated by Richard Philcox. New York: Grove Press, 2008.

Fay, Jennifer. "Dead Subjectivity. White Zombie, Black Baghdad." The Centennial Review 8, no. 1 (2008): 81-101.

Fick, Carolyn. The Making of Haiti. The Saint Domingue Revolution from Below. Knoxville: The University of Tennessee Press, 1990.

Fischer, Sibylle. Modernity Disavowed: Haiti and the Cultures of Slavery in the Age of Revolution. Durham, NC: Duke University Press, 2004.

Girard, Philippe R. Haiti: The Tumultuous History - From Pearl of the Caribbean to Broken Nation. New York: Palgrave Macmillan, 2010.

Glover, Kaiama L. Haiti Unbound: A Spiralist Challenge to the Postcolonial Canon. Liverpool: Liverpool University Press, 2010.

Hallward, Peter. Damming the Flood: Haiti and the Politics of Containment. 2nd ed. London: Verso, 2010.

Hallward, Peter. "Haitian Inspiration. On the Bicentenary of Haiti's Independence." Radical Philosophy 123 (2004): 2-7.

Harvey, William Woodis. Sketches of Hayti. From the Expulsion of the French to the Death of Christophe. London: L.B. Seely, 1827.

Herskovits, Melville J. Life in a Haitian Valley. Garden City, NY: Doubleday, 1971.

Hoermann, Raphael. "A Very Hell of Horrors"? The Haitian Revolution and the Early Transatlantic Haitian Gothic." Slavery \& Abolition 37, no. 1 (2016): 183-205.

Hunt, Alfred N. Haiti's Influence on Antebellum America: Slumbering Volcano in the Caribbean. Baton 
Rouge: Louisiana State University Press, 1988.

Hurston, Zora Neale. Tell My Horse: Voodoo and Life in Haiti and Jamaica. New York: Harper Perennial, 1990.

Hutter [Weston], G. W. "Salt Is Not for Slaves." In The Book of the Living Dead, edited by John Richard Stephens, 369-383. New York: Berkley Books, 2010.

Huxley, Francis. The Invisibles. London: Rupert Hart-Davis, 1966.

James, C. L. R. The Black Jacobins: Toussaint L'Ouverture and the San Domingo Revolution [1938]. London: Penguin, 2001.

Jefferson, Thomas. "Letter to Aaron Burr (11 February 1799)." In Slave Revolution in the Caribbean, 1789-1804: A Brief History with Documents, edited by Laurent Dubois and John D. Garrigus, 160-161. Boston: Bedford/St. Martin's, 2006.

Joseph, Celucien L. "The Haitian Turn': Haiti, the Black Atlantic, and Black Transnational Consciousness." PhD thesis, University of Texas, 2012.

Kaisary, Phillip. The Haitian Revolution in the Literary Imagination: Radical Horizons, Conservative Constraints. Charlottesville: University of Virginia Press, 2014.

King, Alexander, and Rex Hardy, Jr. "Haiti: Where Old Africa and the New World Meet." LIFE (13 December 1937): 27-30.

Laguerre, Michel S. Voodoo and Politics in Haiti. New York: St. Martin's, 1989.

Laroche, Maximilien. "The Myth of the Zombi." In Exile and Tradition: Studies in African and Caribbean Literature, edited by Rowland Smith, 44-61. New York: African, 1976.

Lauro, Sarah Juliet. The Transatlantic Zombie: Slavery, Rebellion, and Living Death. New Brunswick, NJ: Rutgers University Press, 2015.

Lawless, Robert. Haiti's Bad Press: Origins, Developments, and Consequences. Rochester, NY: Schenkman Books, 1992.

MacAlister, Elizabeth. Rara! Vodou, Power, and Performance in Haiti and Its Diaspora. Berkeley: University of California Press, 2002.

MacAlister, Elizabeth. "Slaves, Cannibals, and Infected Hyper-Whites: The Race and Religion of Zombies." Anthropological Quarterly 85, no. 2 (2012): 457-486. Madiou,

Thomas. Histoire d'Haïti. Vol. 3. Port-au-Prince: Courtois, 1848. Mars, Louis

Price. "The Story of the Zombi in Haiti." Man 45 (1945): 38-40.

Marx, Karl. Early Political Writings. Edited by Joseph O'Malley. Cambridge: Cambridge University Press, 1994.

Marx, Karl. Grundrisse [1857]. Translated by Martin Nicolaus. London: Penguin, 1993.

Métraux, Alfred. Voodoo in Haiti. Translated by Hugo Charteris. New Yor

Miller, Paul B. Elusive Origins. The Enlightenment in the Modern Caribbean Historical Imagination. Charlottesville: University of Virginia Press, 2010.

Mintz, Sidney W. "Whitewashing Haiti's History." The Boston Review (January/February 2010). Accessed 15 January 2014. http://bostonreview.net/world/whitewashing-haiti's-history.

Moreau de Saint-Méry, M. L. E. Description topographique, physique, civile, politique et historique de la partie française de l'Isle Saint-Domingue [...]. Vol. 1. Philadelphia, PA: no publisher, 1797.

Munford, Clarence, and Michael Zeuske. "Black Slavery, Class Struggle, Fear and Revolution in St. Domingue and Cuba, 1785-1795." The Journal of Negro History 73, no. 1/4 (1988): 12-32.

Murphy, Kieran M. "White Zombie." Contemporary French and Francophone Studies 15, no. 1 (2011): 47-55.

Nesbitt, Nick. "Haiti, the Monstrous Anomaly." In The Idea of Haiti: Rethinking Crisis and Development, edited by Millery Polyné, 3-26, Minneapolis: University of Minnesota Press, 2013.

Nesbitt, Nick. Universal Emancipation: The Haitian Revolution and the Radical Enlightenment. Charlottesville: University of Virginia Press, 2008.

Nzengou-Tayo, Marie-José. "Haitian Gothic and History. Madison Smartt Bell's Trilogy on Toussaint Louverture and the Haitian Revolution." Small Axe 23, no. 2 (2007): 184-193.

Paravisini-Gebert, Lizabeth. "Colonial and Postcolonial Gothic: The Caribbean." In The Cambridge Companion to Gothic Fiction, edited by Jerrold E. Hoggle, 229-258. Cambridge: Cambridge University Press, 2000.

A Particular Account of the Commencement and Progress of the Insurrection of the Negroes in 
St. Domingo. 4th ed. n.p. [1792].

Patterson, Orlando. Slavery and Social Death. A Comparative Study. Cambridge, MA: Harvard University Press, 1982.

Popkin, Jeremy D. You Are All Free. The Haitian Revolution and the Abolition of Slavery. Cambridge: Cambridge University Press, 2010.

Ramsey, Kate. The Spirits and the Law. Vodou and Power in Haiti. Chicago: University of Chicago Press, 2011.

Renda, Mary V. Taking Haiti: Military Occupation and the Culture of U.S. Imperialism. Chapel Hill: The University of North Carolina Press, 2001.

Seabrook, William B. The Magic Island. London: Harrap, 1929

Seitenfus, Ricardo. "Haïti est la preuve de l'échec de l'aide internationale." Le Temps (21 December 2010). Accessed 21 October 2015. http://www.alterpresse.org/spip.php?article10439. Sheller,

Mimi. Consuming the Caribbean: From Arawaks to Zombies. London: Routledge, 2003. Singham,

Shanti Marie. "Betwixt Cattle and Men: Jews, Blacks, and Women, and the Declaration of the Rights of Man." In The French Idea of Freedom. The Old Regime and the Declaration of Rights of 1789, edited by Dale K. van Kley, 114-153. Stanford, CA: Stanford University Press, 1994.

Sourieau, Marie-Agnès. "Dessalines in Historic Drama and Haitian Contemporary Reality." Small Axe 18 (September 2005): 24-39.

St. John, Sir Spenser. Hayti, or the Black Republic. 2nd ed. New York: Scribner \& Welford, 1889.

Thomson, Ian. "Bonjour Blanc:" A Journey Through Haiti. London: Penguin, 1992.

Trouillot, Michel-Rolph. Silencing the Past: Power and the Production of History. Boston: Beacon Press, 1995.

Trouillot, Michel-Rolph. "The Odd and the Ordinary: Haiti, the Caribbean, and the World." Cimarrón: New Perspectives on the Caribbean 2 (1990):3-12.

Ulysse, Gina Athena. Why Haiti Needs New Narratives: A Post-quake Chronicle. Middletown, CT: Wesleyan University Press, 2015.

Vastey, Baron de. The Colonial System Unveiled. Translated by Chris Bongie. Liverpool: Liverpool University Press, 2014.

White, Ashli. Encountering Revolution. Haiti and the Making of the Early Republic. Baltimore, MD: Johns Hopkins University Press, 2010.

White Zombie (dir. Victor Halperin), USA, 1932. 